\title{
Optimisation of operating parameters for supercritical carbon dioxide extraction of lycopene from industrial tomato waste
}

\section{Olga Migalatiev}

Scientific and Practical Institute of Horticulture and Food Technologies, Moldova

Keywords:

Tomato

Waste

Supercritical

$\mathrm{CO}_{2}$ extraction

Lycopene

Article history:

Received 14.09.2017

Receivedin revised

form 25.11.2017

Accepted 29.12.2017

\section{Corresponding}

author:

Olga Migalatiev

E-mail:

olgamigalatiev@

yahoo.com

DOI: $10.24263 / 2304-$

974X-2017-6-4-10

\section{Abstract}

Introduction. Tomato waste can be used as secondary raw materials for obtaining liposoluble extracts. Lycopene, being a lipophilic compound with antioxidant properties found in tomatoes, it may be extracted using supercritical carbon dioxide from the waste obtained in the industrial processing of tomatoes.

Materials and methods. The tomato waste obtained from the manufacture of tomato juice was collected from "Orhei-Vit" JSC, Orhei, Republic of Moldova. Using the full factorial orthogonal experimental design method, was created the planning matrix in real variables, obtaining 15 extraction regimes by varying the parameters: temperature $\left(36-73{ }^{\circ} \mathrm{C}\right)$, pressure $(18-42 \mathrm{MPa})$ and time $(24-96 \mathrm{~min})$. The content of lycopene was determined by the spectrophotometric method at $502 \mathrm{~nm}$ wavelength.

Results and discussion. Initially, tomato waste was dried from an initial humidity of $80.0 \%$ to a final moisture content of $6.5 \%$. In order to increase the contact surface with carbon dioxide, the tomato waste was milled. Under laboratory conditions, samples of $\mathrm{CO}_{2}$ extracts from tomato waste were obtained at different extraction parameters. The lycopene concentration was taken as the output factor, and it was established the final form of the second order regression equation characterizing the $\mathrm{CO}_{2}$ extraction process of lycopene in the fat-soluble fraction from the tomato waste. The regression equation allowed the optimization of the response using the gradient ascension method, thus establishing the optimal extraction parameters of the bioactive compound - lycopene. The response surface plot described by the second degree polynomial which characterizes the $\mathrm{CO}_{2}$ extraction process of lycopene from tomato waste at constant time, pressure or temperature were graphically represented.

Conclusions. The $\mathrm{CO}_{2}$ extracts from tomato waste are rich in lycopene, the concentration ranging from 10.8 to 47.1 $\mathrm{mg} / 100 \mathrm{~g}$. The optimal parameters for lycopene extraction from tomato waste are the temperature $60-75{ }^{\circ} \mathrm{C}$, the pressure 33-42 MPa and the extraction time 62-68 $\mathrm{min}$. 


\section{Introduction}

With the increase in world trade of tomato products, the tomato processing industry is also expanding. As a consequence (result), the amount of by-products: tomato seeds and skin grows. At present, only a small amount of tomato by-products are sold at low prices and used as feed or fertilizer, but the remaining seeds are thrown away, thus wasting resources and polluting the environment. Tomato seeds are an excellent source of macronutrients: $28 \%$ fat and 29\% protein, and micronutrients: linoleic acid and other unsaturated fatty acids, high levels of essential amino acids such as lysine; without toxic ingredients or nutritional inhibitors. Therefore, the way of extracting nutrients from tomato by-products in order to obtain new products and greater economic value is a challenge. [1]

Secondary products from tomato processing can be used as a raw material for the production of tomato oil, so that the turning effect by transforming waste into a resource is achieved and environmental pollution can be reduced. In addition to the conventional pressing method, it is possible to implement the modern supercritical $\mathrm{CO}_{2}$ extraction technology for the production of tomato seed oil so that the yield of tomato oil can be greatly improved and the quality of the tomato oil could be high. The plant is reliable, the resulting product is safe, and the extraction rate of tomato seed oil is over $95 \%$. Compared to the conventional hot pressing method, the advantage of $\mathrm{CO}_{2}$ extraction is that it avoids the deterioration of bioactive substances and fat-soluble nutritional components that can be stored in essential quantities in tomato seed oil. [1]

Tomato seed oil has a high nutritional value, contains large amounts of unsaturated fatty acids and is a powerful antioxidant that can effectively reduce stress, improve sleep quality, restore skin's natural glow, improve immunity, has anti-aging effects and protects against UV radiation, prevents osteoporosis and can prevent calcium loss. [1]

Tomatoes and tomato waste, respectively, are highlighted by an increased content of lycopene, a powerful antioxidant.

Lycopene is a tetraterpen from the carotenoid family, namely that of carotenes. This is a red, fat-soluble pigment (vegetable colorant) found mainly in tomatoes and various products derived from thermally processed tomatoes. It is named after the Latin name of tomatoes (Solanum lycopersicum), which has the highest natural concentration.

It has a structure consisting of a long chain of conjugated double bonds, with two open rings at the ends.

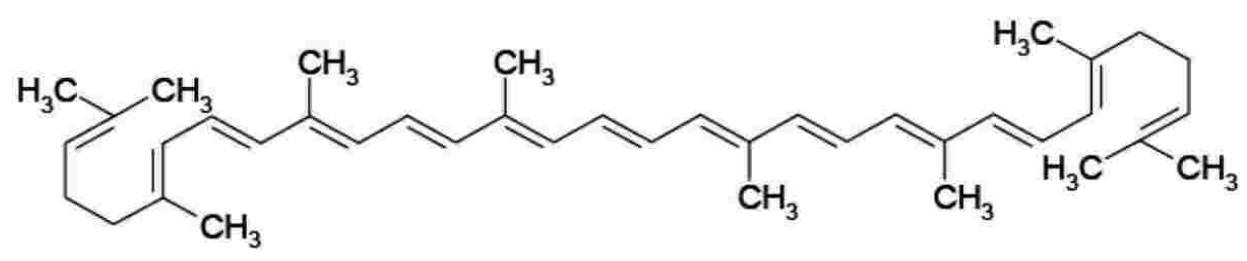

Figure 1. The molecular structure of lycopene

The lycopene molecule is the longest of all carotenoids, which like the $\beta$-carotene, the human body does not synthesize.

Although it has a structure similar to that of the well-known antioxidant $\beta$-carotene, its antioxidant activity is at least 5 times higher. Lycopene protects cells against DNA 
damage and lipid peroxidation, and intervenes in reducing the risk of certain cancers (prostate, digestive, bladder, lung, skin). [2]

The antioxidant activity of lycopene is due to the capture of singlet oxygen from biological systems.

Lycopene is widely used in the alimentary industry as an antioxidant and natural colorant. As antioxidant it is active in non-polar environments, in oils, fats, foods with a lipid content. It has the ability to protect lipids from oxidative degradation by inactivating the reactive forms of oxygen. Namely, the double bonds of the molecules ensure the addition of reactive oxygen. [3]

Thermal treatment or tomato processing does not affect the antioxidant properties of lycopene, on the contrary it increases its availability and is more efficiently assimilated by the human body. $[4,5]$

In laboratory conditions lycopene shows antitoxic properties against various toxic substances such as aflatoxin, cyclosporine or cadmium. [5]

According to the European Food Safety Authority (EFSA Journal 2011; 9 (4): 2031 Scientific opinion on the substantiation of health claims related to lycopene according to Article 13, paragraph 1 of Regulation (EC) No 1924/2006) the Dietary Reference Intake (DRI) of lycopene to have antioxidant effect or a normal cardiac function(in case of cardiovascular disease) is $5-15 \mathrm{mg} /$ day [6]. According to the recommendations of the Guidebook MP 2.3.1. 19150-04 of 2004, (Recommended levels of biologically active substances), the DRI of lycopene is 5-10 $\mathrm{mg}$ (the maximum daily dose is $15 \mathrm{mg}$ ) [7].

This paper presents the content of lycopene in $\mathrm{CO}_{2}$ extracts from tomato waste, obtained at different extraction regimes. Based on the obtained data, it is determined the influence of the extraction parameters: temperature, pressure and time on lycopene concentration in the fat-soluble $\mathrm{CO}_{2}$ extracts from tomato waste.

\section{Materials and methods}

\section{Materials}

Tomato waste was collected from the industrial scale production of tomato juice at "Orhei-Vit" JSC, Orhei, Republic of Moldova.

With the purpose of being used as raw material, tomato waste with an initial moisture content of $80.09 \%$ was dried by the conductive method in Biosec Domus B5 dryer to a final moisture content of $6.50 \%$. One of the basic criteria for carrying out the supercritical $\mathrm{CO}_{2}$ extraction is that the raw material subjected to the extraction of the lipid fraction has a humidity of maximum $10 \ldots 12 \%$. [8]

In order to increase the contact area with the carbon dioxide, to achieve a more efficient extraction, both quantitatively and qualitatively, the tomato waste was milled.

The lipid content in dried tomato waste is $10.5 \%$. [8]

Carbon dioxide is intended for use in the food industry.

The reagents used in analyzes: hexane, ethanol and acetone, meet the quality requirements. 


\section{Methods}

Supercritical $\mathrm{CO}_{2}$ extraction. The supercritical extraction with carbon dioxide from tomato waste was carried out under laboratory conditions at the HA 120-50-01C pilot plant within the Practical Scientific Institute of Horticulture and Food Technology.

The technical parameters of the installation are: $\mathrm{P}_{\max }=50 \mathrm{MPa}(500 \mathrm{~atm}), \mathrm{T}_{\max }=75^{\circ} \mathrm{C}$, volume of the extractor vessel $-1,01$ and maximum extract volume $-0,61$ [8].

From the storage tank, the carbon dioxide is pumped through the heat exchanger into the extractor vessel with raw material - tomato waste. Using the pressure and temperature control system the required extraction pressure and temperature are created in the extractor vessel. Once the supercritical $\mathrm{CO}_{2}$ and the feed reach equilibrium in the extraction vessel, through the manipulation of pressure and temperature to achieve the operating conditions, the extraction process proceeds. The mobile phase, consisting of the superctitical $\mathrm{CO}_{2}$ fluid and the solubilized components, is transferred to the separators I and II where the fluid is reduced by decreasing the pressure of the system. The extract precipitates in the I or II separator while thesuperctitical $\mathrm{CO}_{2}$ fluid is either released to the atmosphere or recycled back to the extractor $[8,9]$.

Determination of Lycopene content. The lycopene from tomato byproducts is extracted using hexane: ethanol: acetone mixture $(2: 1: 1)(\mathrm{v} / \mathrm{v})$ following the Sharma and Le Maquer method, exposed by Alda [10].

One gram of the homogenized samples, and $25 \mathrm{ml}$ of hexane: ethanol: acetone mixture, which was placed into the rotatory mixer for $30 \mathrm{~min}$, adding $10 \mathrm{ml}$ of distilled water and the stirring was continued for another 2 minutes.

The solution was then left to separate into two distinct layers, polar and non-polar. The absorbance was measured at $502 \mathrm{~nm}$, using hexane as a reference sample. The lycopene concentration was calculated using its specific extinction coefficient $(\mathrm{E} 1 \%, 1 \mathrm{~cm})$ of 3150 in hexane at $\lambda=502 \mathrm{~nm}$. The concentration of lycopene is expressed in $\mathrm{mg} / 100 \mathrm{~g}$ product.

$$
C=\frac{E}{3.15} \cdot \frac{20}{m}
$$

$\mathrm{C}$ - lycopene content, $\mathrm{mg} / 100 \mathrm{~g}$

$m$ - mass of product sample, $g$

$E$ - extinction coefficient.

Statistical analysis. The mathematical processing of the obtained data on the supercritical $\mathrm{CO}_{2}$ extraction of lycopene from tomato waste was performed using Microsoft Excel 2007 software.

\section{Results and discussion}

\section{Central factorial experiment composed in the orthogonal plane}

In order to determine practical values of the process parameters, it is necessary to establish interdependencies capable of describing both the nature and the extent of the influences of the input factors, so it is foreseen to determine a mathematical model. 
For the planned experiments, to the influence factors were assigned two levels of variation: a upper level $x_{\text {sup }}$ and a lower level $x_{i n f}$. These two levels are chosen at equal distance from the central level $x_{0}$ of the influence factor, also called base level or zero level.

The zero level indicates the value of the influence factors around which experimental modeling was desired. The interval limited by the lower and upper values of the influence factors defines the experimental field. All influence factors can take values within this range of variation. $[11,12,13]$

During the supercritical- $\mathrm{CO}_{2}$ extraction from tomato waste was examined the oscillation of three process parameters, namely temperature, pressure and time. Respectively, it was obtained the matrix in which the variable parameters of the process were encoded by $X_{1}, X_{2}$ and $X_{3}$ and were noted the minimum, center and maximum values that will be used in supercritical carbon dioxide extraction of liposoluble substances, including lycopene.

The classical matrix of assigning the values of influence factors

Table 1

\begin{tabular}{|l|c|c|c|c|}
\hline \multicolumn{1}{|c|}{ Factor } & Coding & Min. (-) & Center & Max. (+) \\
\hline Temperature, ${ }^{\circ} \mathrm{C}$ & $\mathrm{X}_{1}$ & 40 & 55 & 70 \\
\hline Pressure, $\mathrm{MPa}$ & $\mathrm{X}_{2}$ & 20 & 30 & 40 \\
\hline Time, min. & $\mathrm{X}_{3}$ & 30 & 60 & 90 \\
\hline
\end{tabular}

Each input factor was assigned a coded variable.

The variation range, from minimum (-) to maximum (+), was chosen in accordance with the characteristics of the $\mathrm{CO}_{2}$-extraction plant, so that all experiments were achievable.

To obtain a second-order mathematical model, factorial design of the experiments is used, the most important programs being the composite central programs. When composing the mathematical model in the form of a polynomial of second degree, the number of factors can not be limited to two. Therefore, it should be used $3^{\mathrm{k}}$ programs in which factors are changed to 3 levels. However, these programs become uneconomic or even unrealistic with a number of factors $k \geq 4$, due to the very large number of determinations. In this sense it has been shown that a program with fewer determinations compared to program $3^{\mathrm{k}}$ can be obtained by supplementing a $2^{\mathrm{k}}$ program with certain points of factorial space. $[13,14]$

Results:

$$
\mathrm{N}=\mathrm{N}_{\mathrm{c}}+\mathrm{N}_{\alpha}+\mathrm{N}_{0}
$$

where: $\mathrm{N}$ - total number of determinations;

$\mathrm{N}_{\mathrm{c}}$ - the number of "sphere" determinations;

$\mathrm{N}_{\alpha}$ - the number of "star" points;

$\mathrm{N}_{0}$ - the number of points in the center.

The programming method of the composite central experiment involves completing the $2^{\mathrm{k}}$ base factorial matrix with a number of experiences $\left(\mathrm{N}_{\alpha}=2 \mathrm{k}\right)$, while the other factors are at the base level, and with $\mathrm{N}_{0}$ experiments at the center of the experiment.

Under these circumstances, the total number of experiences is:

$$
\mathrm{N}=2^{\mathrm{k}}+2 \mathrm{k}+\mathrm{N}_{0}(3)
$$


It has been agreed to take as model the orthogonal central matrix.

Initially, the program's center coordinates (zero level $x_{i}^{0}$ ) and intervals of variation $\Delta x_{i}$ were calculated using relations 4 and 5:

$$
\begin{aligned}
x_{i}^{0} & =\frac{x_{i}^{s}+x_{i}^{i}}{2} \\
\Delta x_{i} & =\frac{x_{i}^{s}-x_{i}^{i}}{2}
\end{aligned}
$$

Factors coding was performed according to formula 6 :

$$
\begin{gathered}
X_{i}=\frac{x_{i}-x_{i}^{0}}{\Delta x_{i}} \\
\Delta x_{i}=\frac{X-x_{i}^{0}}{\alpha} \\
X_{1}=\frac{40-55}{15}=-1 ; \\
X_{2}=\frac{20-30}{10}=-1 ; \\
X_{3}=\frac{30-60}{30}=-1 .
\end{gathered}
$$

To complement the matrix with the experiences from no. 9 to 15 , it is necessary to calculate the star points $(+\alpha$ and $-\alpha$ ), multiplied by the coefficients $+1,215$ and $-1,215$ according to formula 7 .

$$
\begin{gathered}
\text { Temperature: }+\alpha: ; X_{+\alpha} X_{+\alpha}=73{ }^{\circ} \mathrm{C} ;-\alpha: ; X_{-\alpha} X_{-\alpha}=36{ }^{\circ} \mathrm{C} ; \\
\text { Pressure: }+\alpha: ; X_{+\alpha} X_{+\alpha}=42 \mathrm{MPa} ;-\alpha: ; X_{-\alpha} X_{-\alpha}=18 \mathrm{MPa} ; \\
\text { Time: }+\alpha: ; X_{+\alpha} X_{+\alpha}=96 \text { min.; }-\alpha: ; X_{-\alpha} X_{-\alpha}=24 \mathrm{~min} .
\end{gathered}
$$

\section{Variation ranges and factor levels}

\begin{tabular}{|l|c|c|c|}
\hline Factor name & Temperature, & Pressure, MPa & Time, min \\
\hline Factor coding & $\boldsymbol{X}_{\boldsymbol{1}}$ & $\boldsymbol{X}_{\mathbf{2}}$ & $\boldsymbol{X}_{\mathbf{3}}$ \\
\hline Upper level $x_{i}^{s}$ & 70 & 40 & 90 \\
\hline Lower level $x_{i}^{i}$ & 40 & 20 & 30 \\
\hline Zero level $x_{i}^{0}$ & 55 & 30 & 60 \\
\hline Intervals of variation $\Delta x_{i}$ & 15 & 10 & 30 \\
\hline Level $+\boldsymbol{\alpha} X_{+\alpha}$ & 73 & 42 & 96 \\
\hline Level $-\boldsymbol{\alpha} X_{-\alpha}$ & 36 & 18 & 24 \\
\hline
\end{tabular}


According to the values of the calculated parameters for the orthogonal model, it is observed that the determined star points are included in the technical characteristics of the installation and allow extraction to be performed under supercritical conditions.

Experiences no 9-14 are performed according to star point values for each factor of influence and their combination with the zero level values of the other factors.

The natural values of input factors in points +1 and -1 are determined from the relation $x_{i}^{0} \pm \Delta x_{i}$.

The values thus obtained are used to perform the experiments. For each experience a measured value of the resultant variable $\mathrm{Y}$ is obtained. These data are used to calculate the regression coefficients of the mathematical model.

The performance of the experiments led to the obtaining of information about the dependent variable $\mathrm{Y}$, in different situations, resulting from the combination of the different coded levels of the independent variables.

Matrix of planning in real variables

Table 3

\begin{tabular}{|c|c|c|c|c|c|c|}
\hline No & $\begin{array}{c}\text { Temperature } \\
{ }^{\circ} \mathbf{C}\end{array}$ & $\begin{array}{c}\text { Presure, } \\
\mathbf{M P a}\end{array}$ & $\begin{array}{c}\text { Time, } \\
\mathbf{m i n}\end{array}$ & $\mathbf{Y}_{\mathbf{A}}$ & $\mathbf{Y}_{\mathbf{B}}$ & $\bar{Y}$ \\
\hline 1 & 40 & 20 & 30 & 10.80 & 12.88 & 11.84 \\
\hline 2 & 70 & 20 & 30 & 25.24 & 25.40 & 25.32 \\
\hline 3 & 40 & 40 & 30 & 25.84 & 22.72 & 24.28 \\
\hline 4 & 70 & 40 & 30 & 47.12 & 35.28 & 41.20 \\
\hline 5 & 40 & 20 & 90 & 13.16 & 15.20 & 14.18 \\
\hline 6 & 70 & 20 & 90 & 28.80 & 29.96 & 29.38 \\
\hline 7 & 40 & 40 & 90 & 25.40 & 26.44 & 25.92 \\
\hline 8 & 70 & 40 & 90 & 40.48 & 44.49 & 42.49 \\
\hline 9 & 37 & 30 & 60 & 19.68 & 16.74 & 18.21 \\
\hline 10 & 73 & 30 & 60 & 36.00 & 32.88 & 34.44 \\
\hline 11 & 55 & 18 & 60 & 16.64 & 16.72 & 16.68 \\
\hline 12 & 55 & 42 & 60 & 29.56 & 29.72 & 29.64 \\
\hline 13 & 55 & 30 & 24 & 22.84 & 22.96 & 22.90 \\
\hline 14 & 55 & 30 & 96 & 26.44 & 28.64 & 27.54 \\
\hline 15 & 55 & 30 & 60 & 26.08 & 26.20 & 26.14 \\
\hline
\end{tabular}

In order to have relevant results on the $\mathrm{CO}_{2}$ extraction process of lycopene from tomato waste, two parallel experiments of the 15 regimes of extractions were performed, at temperature, pressure and time parameters to maximum, minimum and center values and combinations thereof.

When selecting the extraction parameters, were taken into account the characteristics of the pilot plant type HA 120-50-01C, $\left(\mathrm{P}_{\max }=50 \mathrm{MPa}, \mathrm{T}_{\max }=75^{\circ} \mathrm{C}, \mathrm{V}_{\text {cel }}=1,01\right)$ [8], the parameters required to ensure the supercritical state of carbon dioxide $\left(\mathrm{P}_{\mathrm{cr}}=7.377 \mathrm{MPa}, \mathrm{T}_{\mathrm{cr}}\right.$ $=30.978^{\circ} \mathrm{C}, \rho_{\mathrm{cr}}=467.6 \mathrm{~kg} / \mathrm{m}^{3}$ ) [15], but also that these parameters do not affect the quality of the extraction products.

The lycopene concentration in the $\mathrm{CO}_{2}$ extract of tomato waste, obtained with supercritical carbon dioxide, was taken as the output variable. The mean of the response $\bar{Y}$ was the mean of the concentrations of the two parallel experiments $Y_{A}$ and $Y_{B}$. The data obtained are entered in Table 3. 
Thus, the following experiment plannning matrix (Table 4) is obtained:

Table 4

Experiment planning matrix in encoded variables of composed central programming in orthogonal plane

\begin{tabular}{|c|c|c|c|c|c|c|c|c|c|c|c|}
\hline $\mathrm{No}$ & $\boldsymbol{X}_{\boldsymbol{0}}$ & $\boldsymbol{X}_{1}$ & $\boldsymbol{X}_{2}$ & $\boldsymbol{X}_{3}$ & $\boldsymbol{X}_{1} \boldsymbol{X}_{2}$ & $\boldsymbol{X}_{1} \boldsymbol{X}_{3}$ & $\boldsymbol{X}_{2} \boldsymbol{X}_{3}$ & $\boldsymbol{X}_{1}^{2}-\mathbf{0 , 7 3}$ & $\boldsymbol{X}_{2}^{2}-\mathbf{0 , 7 3}$ & $\boldsymbol{X}_{3}^{2}-\mathbf{0 , 7 3}$ & $\bar{Y}$ \\
\hline 1 & + & - & - & - & + & + & + & 0.27 & 0.27 & 0.27 & 11.84 \\
\hline 2 & + & + & - & - & - & - & + & 0.27 & 0.27 & 0.27 & 25.32 \\
\hline 3 & + & - & + & - & - & + & - & 0.27 & 0.27 & 0.27 & 24.28 \\
\hline 4 & + & + & + & - & + & - & - & 0.27 & 0.27 & 0.27 & 41.20 \\
\hline 5 & + & - & - & + & + & - & - & 0.27 & 0.27 & 0.27 & 14.18 \\
\hline 6 & + & + & - & + & - & + & - & 0.27 & 0.27 & 0.27 & 29.38 \\
\hline 7 & + & - & + & + & - & - & + & 0.27 & 0.27 & 0.27 & 25.92 \\
\hline 8 & + & + & + & + & + & + & + & 0.27 & 0.27 & 0.27 & 42.49 \\
\hline 9 & + & -1.21 & 0 & 0 & 0 & 0 & 0 & 0.746 & -0.73 & -0.73 & 18.21 \\
\hline 10 & + & +1.21 & 0 & 0 & 0 & 0 & 0 & 0.746 & -0.73 & -0.73 & 34.44 \\
\hline 11 & + & 0 & -1.21 & 0 & 0 & 0 & 0 & -0.73 & 0.746 & -0.73 & 16.68 \\
\hline 12 & + & 0 & +1.21 & 0 & 0 & 0 & 0 & -0.73 & 0.746 & -0.73 & 29.64 \\
\hline 13 & + & 0 & 0 & -1.21 & 0 & 0 & 0 & -0.73 & -0.73 & 0.746 & 22.90 \\
\hline $14+$ & 0 & 0 & +1.21 & 0 & 0 & 0 & -0.73 & -0.73 & 0.746 & 27.54 \\
\hline 15 & + & 0 & 0 & 0 & 0 & 0 & 0 & -0.73 & -0.73 & -0.73 & 26.14 \\
\hline
\end{tabular}

Factors $X_{12}, X_{13}, X_{23}$ and $X_{123}$ represent the interaction factors, variables that show their mixed influence.

$\bar{Y}$ is the system response, i.e. the average lycopene concentration, $\mathrm{mg} / 100 \mathrm{~g}$ of $\mathrm{CO}_{2}$ extract from tomato waste.

\section{Regression coefficients}

According to formulas 8-12 the regression coefficients of the equation were calculated. 


$$
\begin{gathered}
b_{0}=b_{0}{ }^{\prime}-\phi \sum b_{i i} \\
b_{0}{ }^{\prime}=\frac{1}{N} \sum X_{0 u} Y_{u}(9) b_{i}=\frac{\sum X_{i u} Y_{u}}{\sum X_{i u}^{2}} \\
b_{i j}=\frac{\sum X_{i u} X_{j u} Y_{u}}{\sum\left(X_{i u} X_{j u}\right)^{2}} \\
b_{i i}=\frac{\sum\left(X_{i u}^{2}-\phi\right) Y_{u}}{\sum\left(X_{i u}^{2}-\phi\right)^{2}}
\end{gathered}
$$

The regression coefficients of the equation

Table 5

\begin{tabular}{|c|c|c|c|c|c|c|c|c|c|c|}
\hline $\mathbf{b}_{\mathbf{0}}$ & $\mathbf{b}_{\mathbf{0}}$ & $\mathbf{b}_{\mathbf{1}}$ & $\mathbf{b}_{\mathbf{2}}$ & $\mathbf{b}_{\mathbf{3}}$ & $\mathbf{b}_{\mathbf{1 2}}$ & $\mathbf{b}_{\mathbf{1 3}}$ & $\mathbf{b}_{\mathbf{2 3}}$ & $\mathbf{b}_{\mathbf{1 1}}$ & $\mathbf{b}_{\mathbf{2 2}}$ & $\mathbf{b}_{\mathbf{3 3}}$ \\
\hline 26.01 & 24.50 & 7.48 & 6.29 & 1.37 & 0.60 & 0.17 & -0.43 & 1.66 & -0.49 & 0.91 \\
\hline
\end{tabular}

Since factor encoding has been performed, the regression equation will take the form:

$$
Y=b_{0}{ }^{\prime}+\sum b_{i} X_{i}+\sum b_{i j} X_{i} X_{j}+\sum b_{i i}\left(X_{i}^{2}-\phi\right)
$$

Thus, the following regression equation of the $\mathrm{CO}_{2}$ extraction of lycopene from the tomato waste is obtained:

$$
\begin{gathered}
Y=24,50+7,48 X_{1}+6,29 X_{2}+1,37 X_{3}+0,60 X_{12}+0,17 X_{13}- \\
-0,43 X_{23}+1,66 X_{1}^{2}-0,49 X_{2}^{2}+0,91 X_{3}^{2} Y= \\
=24,50+7,48 X_{1}+6,29 X_{2}+1,37 X_{3}+0,60 X_{12}+ \\
+0,17 X_{13}-0,43 X_{23}+1,66 X_{1}^{2}-0,49 X_{2}^{2}+0,91 X_{3}^{2}
\end{gathered}
$$

Then, according to formulas 14-18, the dispersion of the regression coefficients was calculated.

$$
\begin{gathered}
S_{b_{0}}^{2}=S_{b_{0}^{\prime}}^{2}+\sum \phi^{2} \cdot S_{b_{i i}}^{2} \\
S_{b_{0}^{\prime}}^{2}=\frac{S_{y}^{2}}{N} \\
S_{b_{i}}^{2}=\frac{S_{y}^{2}}{\sum X_{i u}^{2}} \\
S_{b_{i j}}^{2}=\frac{S_{y}^{2}}{\sum\left(X_{i u} X_{j u}\right)^{2}}
\end{gathered}
$$




$$
S_{b_{i u}}^{2}=\frac{S_{y}^{2}}{\sum\left(X_{i u}^{2}-\phi\right)^{2}}
$$

Dispersion of regression coefficients of the equation

Table 6

\begin{tabular}{|c|c|c|c|c|c|c|c|c|c|}
\hline$S_{b_{0}^{\prime}}^{2}$ & $S_{b_{0}^{\prime}}$ & $S_{b_{i}}^{2}$ & $S_{b_{i}}$ & $S_{b_{i j}}^{2}$ & $S_{b_{i j}}$ & $S_{b_{i i}}^{2}$ & $S_{b_{i i}}$ & $S_{b_{0}}^{2}$ & $S_{y}^{2}=S_{0}^{2}$ \\
\hline 0.44 & 0.66 & 0.61 & 0.78 & 0.83 & 0.91 & 1.54 & 1.24 & 2.90 & 2.58 \\
\hline
\end{tabular}

The mean dispersion on the matrix (dispersion of the experiment) was determined according to formula 19 :

$$
S_{0}^{2}=\frac{1}{m} \sum_{i=1}^{m} \sigma_{i}^{2}
$$

Significance evaluation of calculated coefficients was done according to Student's ttest. Calculated values oft $t_{\text {calc. }}$ were determined by the formulas $20-22$.

$$
t_{i}=\frac{\left|b_{i}\right|}{S_{b_{i}}}(20) ; \quad t_{i j}=\frac{\left|b_{i j}\right|}{S_{b_{i j}}}(21) ; \quad t_{i i}=\frac{\left|b_{i i}\right|}{S_{b_{i i}}}(22) .
$$

Table 7

\section{$t_{\text {calc }}$ coefficient values}

\begin{tabular}{|c|c|c|c|c|c|c|c|c|}
\hline $\mathrm{t}_{1}$ & $\mathrm{t}_{2}$ & $\mathrm{t}_{3}$ & $\mathbf{t}_{\mathbf{1 2}}$ & $\mathbf{t}_{\mathbf{1 3}}$ & $\mathbf{t}_{\mathbf{2 3}}$ & $\mathrm{t}_{11}$ & $\mathbf{t}_{\mathbf{2 2}}$ & $\mathbf{t}_{\mathbf{3 3}}$ \\
\hline 9.57 & 8.06 & 1.75 & 0.66 & 0.19 & 0.48 & 1.33 & 0.39 & 0.73 \\
\hline
\end{tabular}

Student's t-table $t_{S t}$ coefficient is determined from the Student distribution table, where is indicated the number of degrees of freedom $f$, the probability $P$, or the confidence $q$.

It is known that: $b_{i}$ is significant if

$b_{i} b_{i} \quad$ is insignificant if $\left|t_{i}\right|<t_{S t}$

By comparing the calculated values of the Student's t-test and the Student's t-table $t_{S t}$, it was determined that the insignificant coefficients $b$ are $b_{12}, b_{13}, b_{23}, b_{22}$ and $b_{33}$, and respectively $X_{12}, X_{13}, X_{23}, X_{22}, X_{33}$ are insignificant factors.

Considering only significant regression coefficiants, the model corresponding to the system is represented by the followingregression equation in the final form:

$$
\begin{aligned}
& Y=24,80+7,48 X_{1}+6,29 X_{2}+1,37 X_{3}+1,66 X_{1}^{2} Y= \\
& =24,80+7,48 X_{1}+6,29 X_{2}+1,37 X_{3}+1,66 X_{1}^{2}
\end{aligned}
$$


This is the regression equation without the five insignificant regression coefficients. After removing the insignificant terms it is assumed that the $\hat{Y}$ answer is recalculated (table 8).

\section{Reference data for testing the suitability of the regression equation}

Table 8

\begin{tabular}{|c|c|c|c|c|c|c|c|c|c|c|}
\hline No & $\begin{array}{c}\mathbf{T}, \\
{ }^{\circ} \mathbf{C}\end{array}$ & $\begin{array}{c}\mathbf{P}, \\
\mathbf{M P a}\end{array}$ & $\begin{array}{c}\mathbf{t}, \\
\mathbf{m i n}\end{array}$ & $\mathbf{Y}_{\mathbf{A}}$ & $\mathbf{Y}_{\mathbf{B}}$ & $\bar{Y}$ & $\boldsymbol{\sigma}^{2}$ & $\widehat{Y}$ & $\left(\bar{Y}_{i}-\hat{Y}_{i}\right)$ & $\left(\bar{Y}_{i}-\hat{Y}_{i}\right)^{2}$ \\
\hline 1 & 40 & 20 & 30 & 10.80 & 12.88 & 11.84 & 2.16 & 9.23 & 2.61 & 6.83 \\
\hline 2 & 70 & 20 & 30 & 25.24 & 25.40 & 25.32 & 0.01 & 24.18 & 1.14 & 1.29 \\
\hline 3 & 40 & 40 & 30 & 25.84 & 22.72 & 24.28 & 4.87 & 21.81 & 2.47 & 6.08 \\
\hline 4 & 70 & 40 & 30 & 47.12 & 35.28 & 41.20 & 70.09 & 36.77 & 4.43 & 19.64 \\
\hline 5 & 40 & 20 & 90 & 13.16 & 15.20 & 14.18 & 2.08 & 11.96 & 2.22 & 4.94 \\
\hline 6 & 70 & 20 & 90 & 28.80 & 29.96 & 29.38 & 0.67 & 26.91 & 2.47 & 6.08 \\
\hline 7 & 40 & 40 & 90 & 25.40 & 26.44 & 25.92 & 0.54 & 24.54 & 1.38 & 1.89 \\
\hline 8 & 70 & 40 & 90 & 40.48 & 44.49 & 42.49 & 8.04 & 39.50 & 2.99 & 8.91 \\
\hline 9 & 37 & 30 & 60 & 19.68 & 16.74 & 18.21 & 4.32 & 15.80 & 2.41 & 5.79 \\
\hline 10 & 73 & 30 & 60 & 36.00 & 32.88 & 34.44 & 4.87 & 33.90 & 0.54 & 0.29 \\
\hline 11 & 55 & 18 & 60 & 16.64 & 16.72 & 16.68 & 0.00 & 16.52 & 0.16 & 0.03 \\
\hline 12 & 55 & 42 & 60 & 29.56 & 29.72 & 29.64 & 0.01 & 31.75 & -2.11 & 4.45 \\
\hline 13 & 55 & 30 & 24 & 22.84 & 22.96 & 22.90 & 0.01 & 23.20 & -0.30 & 0.09 \\
\hline 14 & 55 & 30 & 96 & 26.44 & 28.64 & 27.54 & 2.42 & 26.50 & 1.04 & 1.07 \\
\hline 15 & 55 & 30 & 60 & 26.08 & 26.20 & 26.14 & 0.01 & 24.85 & 1.29 & 1.66 \\
\hline
\end{tabular}

According to the regression equation, was determined the $\hat{Y}$ value for each row from the planar matrix. Was calculated the difference between the mean value $\bar{Y}$ obtained experimentally and the $\hat{Y}$ value calculated from the regression equation. These differences $\left(\bar{Y}_{i}-\hat{Y}_{i}\right)$ were raised to the square $\left(\bar{Y}_{i}-\hat{Y}_{i}\right)^{2}$ and it was calculated their sum.

For the analyzed case the sum of the square differences is $\sum\left(\bar{Y}_{i}-\hat{Y}_{i}\right)^{2}=69,05$

The assessment of the suitability dispersion of the model is determined by formula:

$$
S_{a d}^{2}=\frac{m}{N-l} \sum\left(\bar{Y}_{i}-\hat{Y}_{i}\right)^{2}
$$

Where $m$ - the number of parallel experiments

$(\mathrm{N}-\mathrm{l})$ - the number of degrees of freedom of the remaining dispersion

$N$ - number of experiments

$l$ - the number of significant regression coefficients, including $b_{0}$ 
According to the formula 23, residual dispersion is equal to $S_{a d}^{2}=\frac{2}{15-5} 69,05=13,81$

Verification of the reliability of the experimental data was performed based on the Fisher criterion.

$$
F=\frac{S_{a d}^{2}}{S_{y}^{2}}
$$

Thus,

$$
F_{\text {calc }}=\frac{13,81}{6,67}=2,07
$$

To verify the veracity of the hypothesis on the suitability of the model, the number of degrees of freedom $f_{1}$ (for residual dispersion $S_{a d}^{2}$ ) and $f_{2}$ (for remaining dispersion $S_{y}^{2}$ ) was determined and the table value of Fisher test $F_{\operatorname{tab}\left(q ; f_{1} ; f_{2}\right)}$ was found depending on degrees of freedom and chosen confidence level $P$ or uncertainty $q$.

$$
\begin{gathered}
q=0,05 \\
f_{1}=N-l=15-7=8 \\
f_{2}=N(m-1)=15(2-1)=15 \\
F_{t a b(0,05 ; ; ; 15)}=2,64
\end{gathered}
$$

Since $2.07<2.64$, ie $F_{c a l c}<F_{t a b(0,05 ; ; ; 15)}$ it shows that the equation of regression is true, the orthogonal model is also true.

\section{Gradient optimization [16]}

The regression equation allows the optimization of the output parameters (the response) using the gradient method.

Gradient elevation value was calculated for each input factor.

$$
P\left(X_{i}\right)=\Delta X_{i} \cdot b_{i}=\left\{X_{i}(+)-X_{i}(-)\right\} \cdot b_{i}
$$

The theoretical step to optimize the response for the $\mathrm{CO}_{2}$ extraction process of lycopene from tomato waste:

$$
\begin{aligned}
& P\left(X_{1}\right)=\left\{X_{1}(+)-X_{1}(-)\right\} \cdot b_{1}=(70-40) \cdot b_{1}=30 \cdot 7,48=224,40 \\
& P\left(X_{2}\right)=\left\{X_{2}(+)-X_{2}(-)\right\} \cdot b_{2}=(40-20) \cdot b_{2}=20 \cdot 6,29=125,80 \\
& P\left(X_{3}\right)=\left\{X_{3}(+)-X_{3}(-)\right\} \cdot b_{3}=(90-30) \cdot b_{3}=60 \cdot 1,37=82,20
\end{aligned}
$$

Since it is unrealistic to vary the input factors with such values of the theoretical steps, to predict the gradient step of ascension, an intuitive coefficient of $K_{i n .}=44.88$ was used so that the values of the steps were achievable.

Thus, the recalculated step will be: 


$$
\begin{aligned}
& P^{*}\left(X_{i}\right)=\frac{P\left(X_{i}\right)}{K_{\text {in. }}} \\
P^{*}\left(X_{1}\right)=5,00 \quad P^{*}\left(X_{2}\right)=2,80 & P^{*}\left(X_{3}\right)=1,80
\end{aligned}
$$

It has been established that there are required the following experiments with the recalculated step, presented in Table 9 .

Table 9

Planned experiences with the recalculated step

\begin{tabular}{|l|c|c|c|c|c|}
\hline Variable parameters & Center & $\mathbf{1}$ & $\mathbf{2}$ & $\mathbf{3}$ & $\mathbf{4}$ \\
\hline $\mathrm{X}_{1}-$ temperature, ${ }^{\circ} \mathrm{C}$ & 55 & 60 & 65 & 70 & 75 \\
\hline $\mathrm{X}_{2}-$ pressure, $\mathrm{MPa}$ & 30 & 33 & 36 & 39 & 42 \\
\hline $\mathrm{X}_{3}-$ time, $\min$ & 60 & 62 & 64 & 66 & 68 \\
\hline
\end{tabular}

Knowing the factors that influence the $\mathrm{CO}_{2}$ extraction process of lycopene from tomato waste, according to the table it can be chosen an optimum.

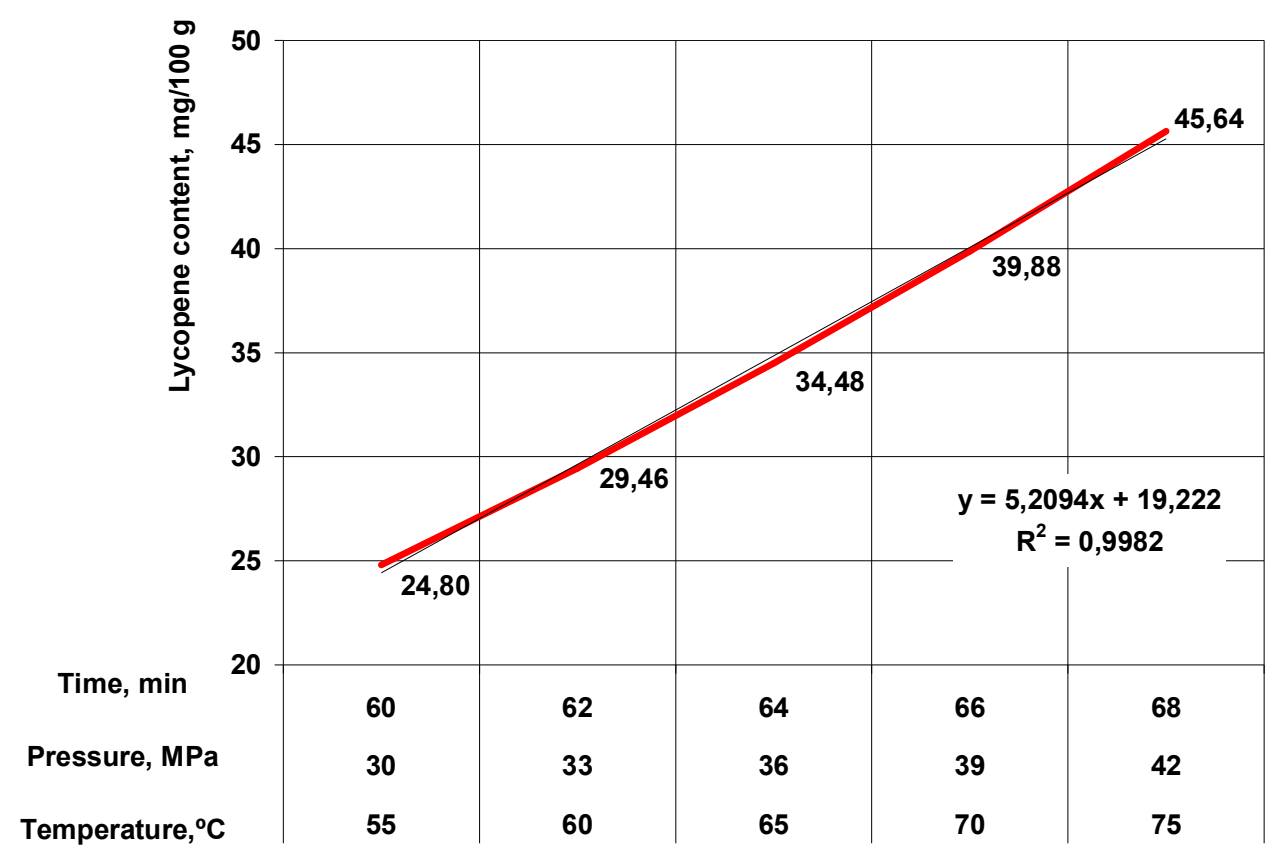

Figure 2. The calculated lycopene content according to the obtained equation at envisaged parameters with the recalculated step 


\section{- Food Technology -}

Analyzing the data from Figure 2, it is noted that increasing the temperature by $5.0{ }^{\circ} \mathrm{C}$, the pressure by $3.0 \mathrm{MPa}$ and the extraction time by 2.0 minutes, the lycopene content increases with 4.66 to $5.76 \mathrm{mg} / 100 \mathrm{~g}$ of extract.

\section{Graphs of the response surfaces}

In order to obtain the graphs of response surfaces in the final form of regression equation : $\hat{Y}=24,80+7,48 X_{1}+6,29 X_{2}+1,37 X_{3}+1,66 X_{1}^{2}$ the parameters $\mathrm{X}_{1}, \mathrm{X}_{2}, \mathrm{X}_{3}$ are replaced with the expressions:

$$
\begin{gathered}
\mathrm{X}_{1}=\left(\mathrm{T}-\mathrm{T}_{0}\right) / \Delta \mathrm{T} ; \text { or }: \mathrm{X}_{1}=(\mathrm{T}-55) / 15 \\
\mathrm{X}_{2}=\left(\mathrm{P}-\mathrm{P}_{0}\right) / \Delta \mathrm{P} ; \text { or }: \mathrm{X}_{2}=(\mathrm{P}-30) / 10 \\
\mathrm{X}_{3}=\left(\mathrm{t}-\mathrm{t}_{0}\right) / \Delta \mathrm{t} \text {; or }: \mathrm{X}_{3}=(\mathrm{t}-60) / 30
\end{gathered}
$$

Therefore, the final form of the second degree equation describing the lycopene $\mathrm{CO}_{2}$ extraction from tomato waste is:

$$
\widehat{Y}=24,80+7,48(T-55) / 15+6,29(P-30) / 10+1,37(t-60) / 30+1,66((T-55) / 15)^{2}
$$

The plot of response surface of lycopene concentration in the $\mathrm{CO}_{2}$ extracts from tomato waste, at 1 constant input factor (for minimum and maximum values) and 2 variable inputs were modeled.

At constant temperature $\mathrm{T}=35^{\circ} \mathrm{C}$ (Figure 3a), the minimum and maximum lycopene content calculated by the obtained formula is:

$$
\begin{gathered}
\widehat{Y}_{\min }=8.63 \mathrm{mg} / 100 \mathrm{~g} \text {, at } \mathrm{P}=18 \mathrm{MPa}, \mathrm{t}=25 \mathrm{~min} \\
\widehat{Y}_{\max }=28.81 \mathrm{mg} / 100 \mathrm{~g} \text {, at } \mathrm{P}=45 \mathrm{MPa}, \mathrm{t}=95 \mathrm{~min}
\end{gathered}
$$

According to the mathematical model, at $75^{\circ} \mathrm{C}$ a maximum lycopene content of 48.76 $\mathrm{mg} / 100 \mathrm{~g}$ is obtained at $\mathrm{P}=45 \mathrm{MPa}$ and $\mathrm{t}=95 \mathrm{~min}$, and the minimum lycopene content of $28.58 \mathrm{mg} / 100 \mathrm{~g}$ at $\mathrm{P}=18 \mathrm{MPa}, \mathrm{t}=25 \mathrm{~min}$ (Figure $3 \mathrm{~b}$ ).

If the pressure is constant, namely for $\mathrm{P}_{\min }=15 \mathrm{MPa}$ (Figure $4 \mathrm{a}$ ), the minimum lycopene concentration is equal to $6.74 \mathrm{mg} / 100 \mathrm{~g}\left(35^{\circ} \mathrm{C}\right.$ and $\left.25 \mathrm{~min}\right)$ and the maximum concentration is up to $29.89 \mathrm{mg} / 100 \mathrm{~g}\left(75^{\circ} \mathrm{C}\right.$ and $\left.95 \mathrm{~min}\right)$.

In the case when pressure is constant, for $\mathrm{P}_{\max }=45 \mathrm{MPa}$ (Figure $4 \mathrm{~b}$ ), the minimum lycopene concentration is $25.61 \mathrm{mg} / 100 \mathrm{~g}\left(35^{\circ} \mathrm{C}\right.$ and $\left.25 \mathrm{~min}\right)$ and the maximum concentration reaches $48.76 \mathrm{mg} / 100 \mathrm{~g}\left(75^{\circ} \mathrm{C}\right.$ and $\left.95 \mathrm{~min}\right)$.

At a constant time of 25 minutes, the lycopene concentration would be at least 5.43 $\mathrm{mg} / 100 \mathrm{~g}$ at $35^{\circ} \mathrm{C}$ and $18 \mathrm{MPa}$, and at most $42.36 \mathrm{mg} / 100 \mathrm{~g}$ at $75^{\circ} \mathrm{C}$ and $45 \mathrm{MPa}$ (Figure $5 a)$.

For the duration of the 120 minute constant extraction, according to the response area obtained according to the final equation, the minimum concentration of lycopene is 18.45 $\mathrm{mg} / 100 \mathrm{~g}$ at $35^{\circ} \mathrm{C}$ and $18 \mathrm{MPa}$ and the maximum concentration is $55.38 \mathrm{mg} / 100 \mathrm{~g}$ at $75^{\circ} \mathrm{C}$ and $45 \mathrm{MPa}$ (Figure 5b). 


\section{- Food Technology}

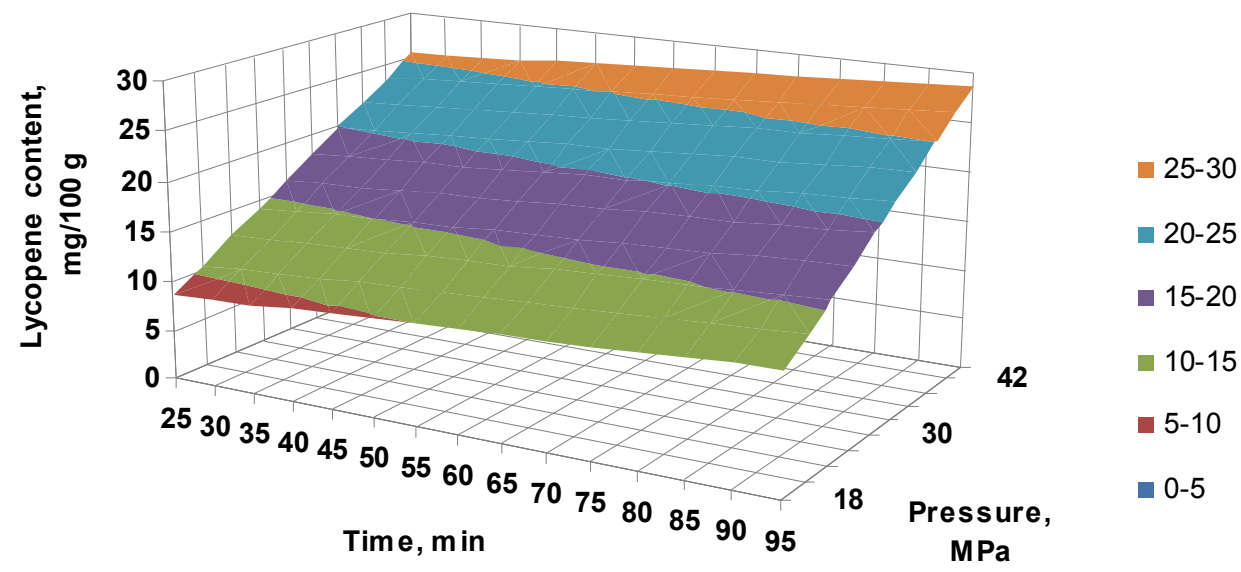

$a$

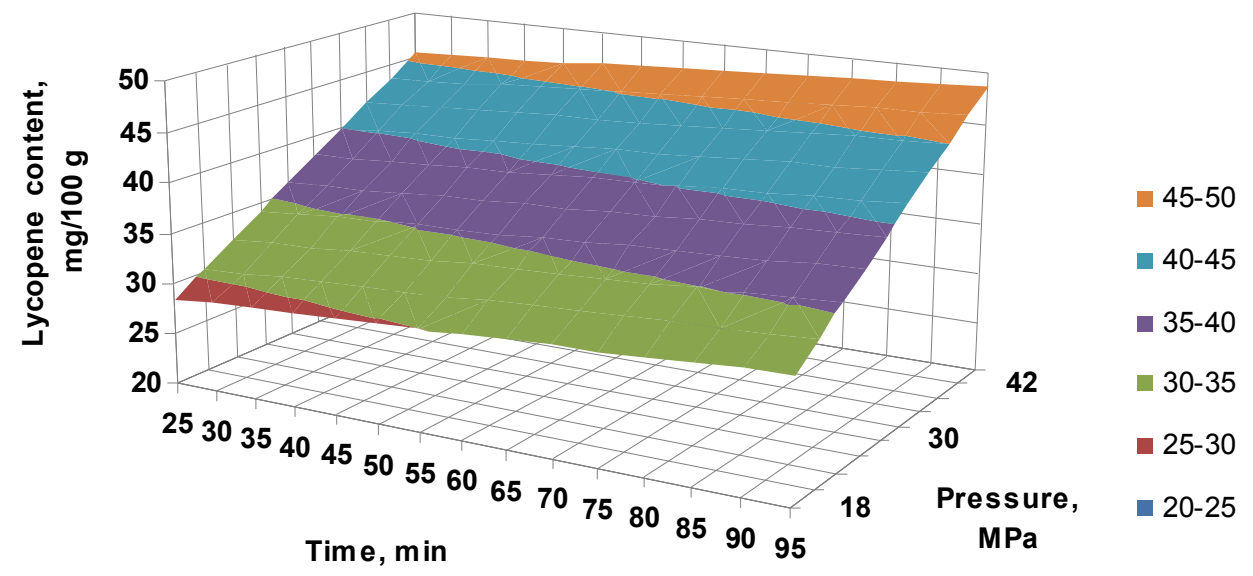

b

Figure 3. The response surface plot of tomato waste $\mathrm{CO}_{2}$ extraction : lycopene content vs. extraction pressure and time at constant temperature

$$
\mathrm{a}-35^{\circ} \mathrm{C} ; \mathrm{b}-75^{\circ} \mathrm{C}
$$




\section{— Food Technology —}

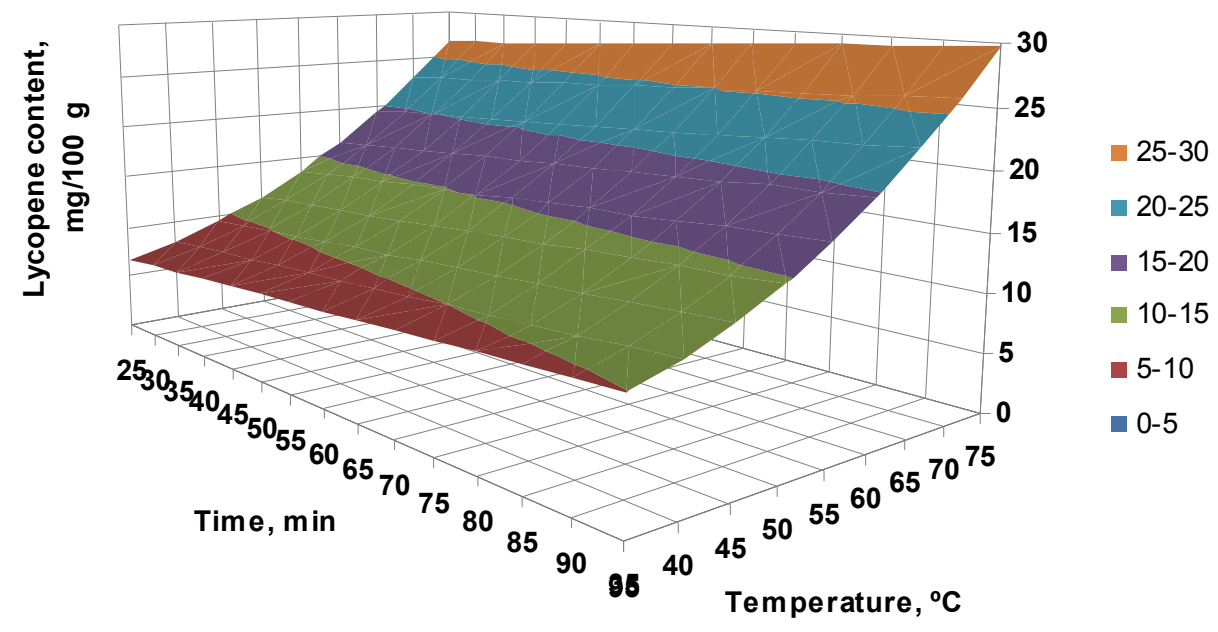

- 25-30

- 20-25

- $15-20$

- 10-15

- 5-10

- $0-5$

$a$

$\square 0-50$

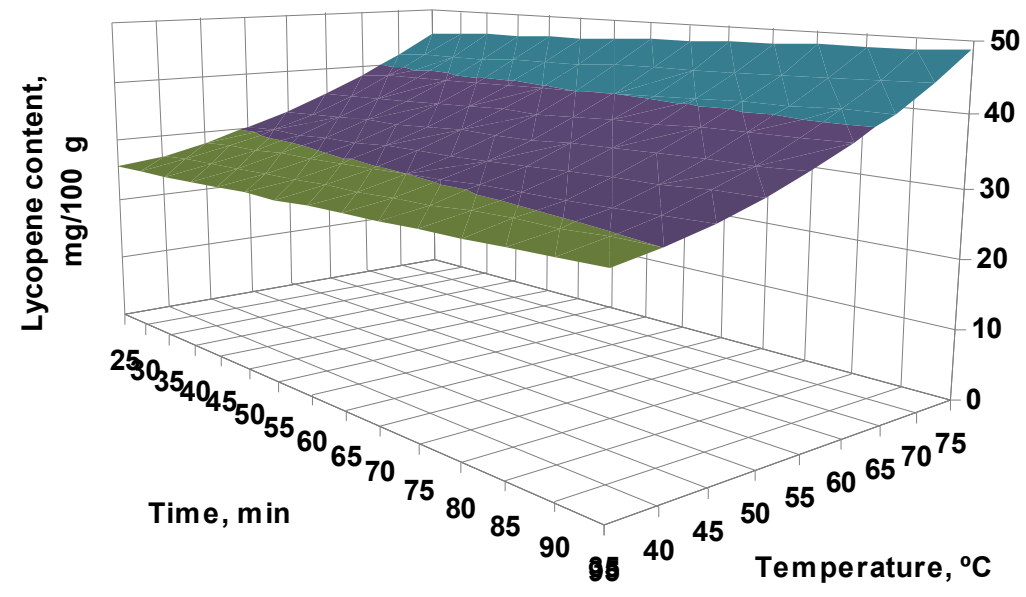

- $30-40$

- 20-30

- 10-20

- 0-10

$\boldsymbol{b}$

Figure 4. The response surface plot of tomato waste $\mathrm{CO}_{2}$ extraction : lycopene content vs. extraction temperature and time at constant pressure $a-15 \mathrm{Mpa} ; b-45 \mathrm{MPa}$ 


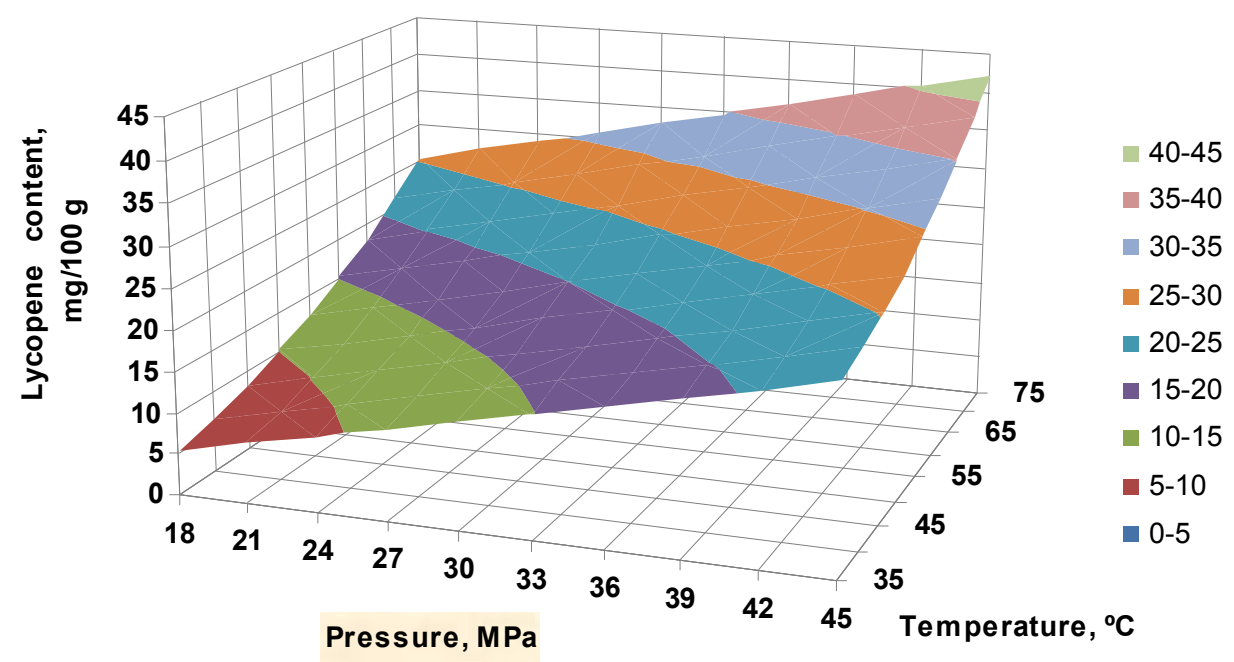

$a$

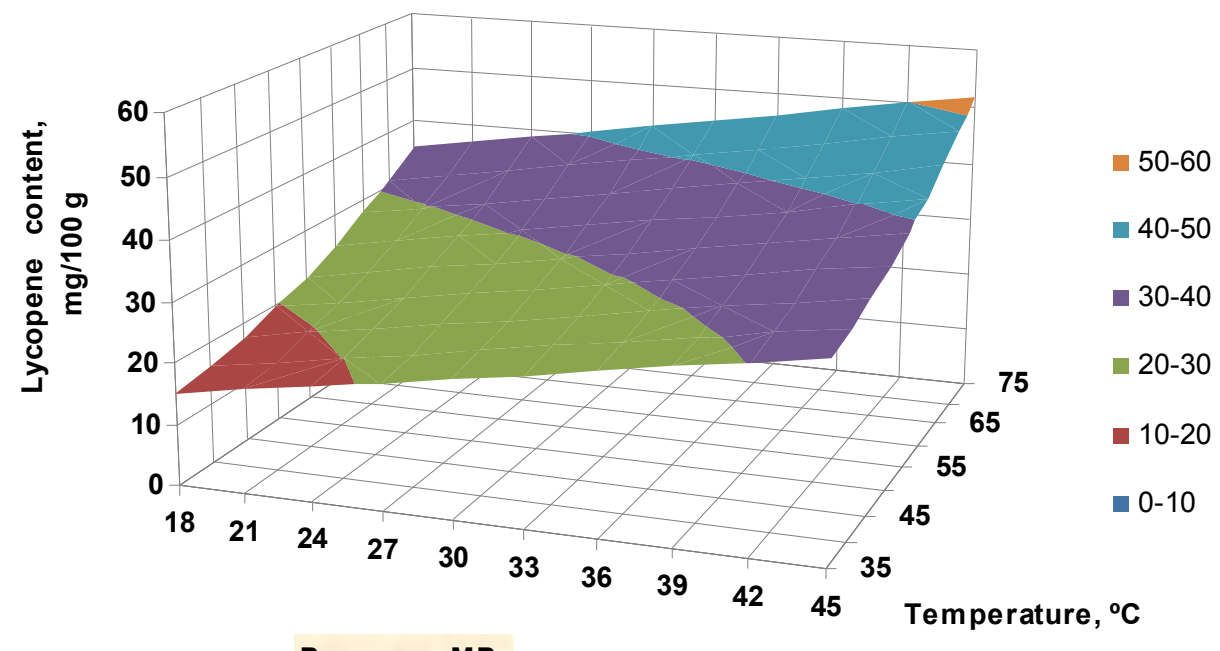

Pressure, MPa

Figure 5. The response surface plot of tomato waste $\mathrm{CO}_{2}$ extraction : lycopene content vs. extraction pressure and temperature at constant time $a-25$ min; $b-95$ min 
The content of lycopene in the $\mathrm{CO}_{2}$ extract from tomato waste varies between 10,80 $47,12 \mathrm{mg} / 100 \mathrm{~g}$, ie on average $28,96 \mathrm{mg} / 100 \mathrm{~g}$ of $\mathrm{CO}_{2}$-extract, about 2-9 times higher than Recommended Daily Amount (RDA), 5-15 mg/day [6, 7].

In order to provide the human body with $15 \%$ of the RDA [17] of lycopene, a portion of the consumed product must contain at least $0.75 \mathrm{mg}$ of lycopene.

\section{Conclusion}

Tomato waste can be used as a secondary raw material for the extraction of lycopene in liposoluble $\mathrm{CO}_{2}$ extract.

For supercritical $\mathrm{CO}_{2}$ extraction parameters: $\mathrm{T}=36-73{ }^{\circ} \mathrm{C} ; \mathrm{P}=18-42 \mathrm{MPa}$ and $\mathrm{t}=24-96$ min, the lycopene content in $\mathrm{CO}_{2}$ fatty soluble extracts from tomato waste varies in the range from 10.80 to $47.12 \mathrm{mg} / 100 \mathrm{~g}$.

The greatest influence on the extracting process of lycopene in $\mathrm{CO}_{2}$ extracts from tomato waste has the temperature, followed by pressure, and the duration of the process has the least influence.

The final form of the second degree equation describing the $\mathrm{CO}_{2}$ extraction of lycopene from tomato waste has been established:

$$
\widehat{Y}=24,80+7,48(T-55) / 15+6,29(P-30) / 10+1,37(t-60) / 30+1,66((T-55) / 15)^{2}
$$

The optimal parameters of supercritical $\mathrm{CO}_{2}$ extraction of lycopene from tomato waste are temperature $60-75^{\circ} \mathrm{C}$, pressure $33-42 \mathrm{MPa}$ and time $62-68 \mathrm{~min}$.

\section{References}

1. (2015), Method for producing tomato seed oil under super-critical $\mathrm{CO}_{2}$ auxiliary squeezing. Brevet de invenţie CN104357208 A. 2015-02-18.

2. Banu C. (2010), Alimente funcţionale, suplimente alimentare şi plante medicinale, Editura ASAB, Bucureşti.

3. (2014), Method for supercritical carbon dioxide extraction of lycopene in watermelon Brevet de inventie CN101891580 B. 2014-05-14.

4. Tatarov P. (2017), Chimia Produselor alimentare, Universitatea tehnică a Moldovei, Facultatea Tehnologie şi Management în Industria Alimentară, Chişinău.

5. Pokorny J., Yanishlieva N., Gordon M. (2001), Antioxidants in food, Practical applications, Woodhead Publishing in Food Science and Technology, CRC Press, Cambridge.

6. EFSA Panel on Dietetic Products, Nutrition and Allergies (NDA) (2011), Scientific Opinion on the substantiation of health claims related to lycopene and protection of DNA, proteins and lipids from oxidative damage, protection of the skin from UVinduced (including photo-oxidative) damage, contribution to normalcardiac function, and maintenance of normal vision (pursuant to Article 13(1) of Regulation (EC) No 1924/2006, EFSA Journal, 9(4):2031 
7. MP 2.3.1. 19150-04 (2004), Ratsionalnoe pitanie, Rekomenduemye urovni potrebleniia pishchevykh i biologicheski aktivnykh veshchestv, Federalnaia sluzhba po nadzoru v sfere zashchity prav potrebitelei i blagopoluchiia cheloveka.

8. Migalatiev O. (2016), Deşeurile de tomate - materie primă secundară pentru $\mathrm{CO}_{2}$ extracţia supercritică, Pomicultura, Viticultura şi Vinificația, 3(63), pp. 27-34, ISSN 1857-3142.

9. Boye I. J., Arcand Y. (2012), Green technologies in food production and processing. Food Research and Development Centre Agriculture and Agri-Food Canada, Saint Hyacinthe, Food Engineering Series, Springer.

10. Alda L. M., Gogoaşă I., Bordean D.-M., Gergen, I., Alda S.; Moldovan C.; Niţă L. (2009) Lycopene content of tomatoes and tomato products. Journal of Agroalimentary Processes and Technologies, 15(4), pp. 540-542.

11. Cicala E. F. (1999), Metode de prelucrare statistica a datelor experimentale, Editura Politehnica, Timisoara.

12. Leoveanu I. S. (2006), Optimizarea proceselor tehnologice, Vol.1. Aplicaţii generale. Ed. Luxlibris.

13. Baron T. (1995), Statisticăteoretică şi economică, Editura Didactică şi Pedagogică, Bucureşti.

14. Gajdanin A. N., Efremova S. A. (2008), Ispol'zovanie metoda kompozicionnogo planirovanija jeksperimenta dlja opisanija tehnologicheskih processov, VolgGTU., Volgograd.

15. Pioro I., Mokry S. (2011), Thermophysical Properties at Critical and Supercritical Pressures, Heat Transfer - Theoretical Analysis, Experimental Investigations and Industrial Systems.

16. Baerle A. Macari A. (2014), Modelarea matematică a experimentului. Suport teoretic de curs, Editura Tehnica-UTM, Chisinău.

17. Hotărârea de Guvern nr. 538 din 02.09.2009, Regulamentul sanitar privind suplimentele alimentare, punct. 15 . 